\title{
Demonstrating deep biosphere activity in the geological record of lake sediments, on Earth and Mars
}

John Parnell ${ }^{1}$, Sean McMahon ${ }^{2}$ and Adrian Boyce ${ }^{3}$

${ }^{1}$ School of Geosciences, University of Aberdeen, Aberdeen AB24 3UE, UK

${ }^{2}$ Department of Geology \& Geophysics, Yale University, 210 Whitney Avenue, New Haven, CT, USA

${ }^{3}$ Scottish Universities Environmental Research Centre, East Kilbride, Glasgow G75 0QF, UK

Abstract

The investigation of Gale Crater has highlighted the occurrence of lake sediments in the geological record of Mars. Lacustrine basins include a diversity of potential habitats for life. An analogue terrestrial lacustrine basin of Devonian age in Scotland contains sulphide minerals in several settings where subsurface microbial colonization can be envisaged. Sulphur isotope compositions for the sulphides imply that they were precipitated by microbial sulphate reduction. The data suggest that the search for life in martian lacustrine basins should include investigation of potential subsurface habitats, and that any sulphides in martian lacustrine basins could be useful indicators in the search for life.

Introduction

The recognition of an extensive deep biosphere on Earth, and the advantages of subsurface niches for putative life on other planets, have contributed to the serious consideration of deep biosphere targets in the search for evidence of life on Mars (Fisk \& Giovannoni 1999, Weiss et al. 2000, Michalski et al. 2013). The lacustrine infills of impact craters on Mars are an especially attractive target, as they may once have been sites of elevated heat flow (driving the circulation and surfaceexpression of liquid water) and nutrient accumulation, enhancing habitability (e.g. Arp 1995). Sulphate minerals have been detected in numerous crater-hosted sediments thought to be groundwater-fed palaeolake deposits, where they have been interpreted as evaporites (sulphate also fills diagenetic veins on Mars; Ehlmann \& Edwards 2014 and references therein). The importance of lacustrine deposits on Mars has recently been emphasized by discoveries in Gale Crater by the Curiosity Rover (Grotzinger et al. 2014, 2015), that also include a sulphate-rich lacustrine mudstone unit. The mudstone contains traces of organic matter (Ming et al. 2014) and a cross-cutting sediment injection structure (Grotzinger et al. 2014).

Lacustrine deposits on Earth are natural archives of life in and around lakes (e.g. Buatois \& Mángano 1998, Schnurrenberger et al. 2003), preserved as abundant sedimentary organic matter and common carbonaceous fossils. Microfossils are commonly reported within lacustrine sediments including evaporitic sulphates (Schopf et al. 2012). This study sought to investigate whether lacustrine basins can additionally record the presence of the deep biosphere, i.e., microbial populations that develop within the sediments after burial, which might produce geochemical traces in several settings (Fig. 1). Bacterial sulphate reduction (BSR) is known to be a widespread metabolic process in the subsurface (McMahon \& Parnell 2014), where along with other microbial activity it is responsible for mineralogical alteration and neoformation (diagenesis) and is a common source of 
sulphide minerals (e.g. Cavalazzi et al. 2014). The iron sulphide pyrite occurs widely in shales in particular, where a supply of organic matter fuels microbial activity and biomass growth (Raiswell \& Berner 1986). In this study, sampling of sulphide minerals was undertaken in the Devonian Orcadian Basin, Scotland (Fig. 2), several aspects of which provide useful analogues for Mars. The basin was sulphate-rich, and it shows widespread evidence for sulphate precipitation at the sediment surface and sulphide precipitation in the subsurface (Muir \& Ridgway 1975, Duncan \& Buxton 1995). Because bacteria preferentially metabolise the lighter isotope of sulphur $\left({ }^{32} \mathrm{~S}\right)$, the sulphide minerals precipitated by BSR are characteristically depleted in the heavier isotope $\left({ }^{34} \mathrm{~S}\right.$; e.g. Machel, 2001). We therefore measured the sulphur isotope composition of the sulphides in order to assess if their precipitation was biologically mediated, and thereby indicative of deep biosphere activity, which would suggest that the possibility of deep biosphere activity also be considered in martian lacustrine basins.

\section{Geological Setting}

The Orcadian Basin is a 5+ km-thick package of continental sediments, deposited in an extensional basin of $10 \mathrm{~s}$ of $\mathrm{km}$ wide during the mid-Devonian. The sediments include several kilometres thickness of lacustrine sediments, deposited in cycles reflecting fluctuations in water level and/or climate (Donovan 1980, Marshall \& Hewett 2003, Andrews \& Trewin 2010). The lake sediments are predominantly siltstones, which interdigitate with fluvial and aeolian sandstones towards the basin margins. A small proportion of the lake sediments is organic-rich and generated oil during burial (Trewin 1989, Duncan \& Buxton 1995). The sediments include widespread pseudomorphs after gypsum (Parnell \& Janaway 1990, Astin \& Rogers 1991), indicating sulphate-rich pore waters. Offshore, sulphate evaporitic sediments are preserved unreplaced (Duncan \& Buxton 1995). In the middle of the basin is an inlier of the underlying crystalline basement (Strachan 2003), which is a palaeotopographic high comparable in nature to the central uplift found in larger impact craters (Kenkmann et al. 2005). As in craters (Osinski et al. 2013), the basement inlier was a focus of hydrothermal activity during sedimentation, including precipitation of base metal sulphide minerals (Gallagher et al. 1971, Plant et al. 1986). Further hydrothermal activity occurred after the cessation of sedimentation, evidenced by widespread calcite veins with traces of sulphides (Gallagher et al. 1971, McMahon et al. 2012, Dichiarente et al. 2016). The lacustrine sediments, sulphate-rich chemistry and basement high are all characteristics pertinent to Mars. The rocks are well-exposed, and well-studied, and have proved valuable analogues for planetary science studies (McMahon et al. 2012, Hutchinson et al. 2014)

\section{Sulphide mineralization}

The distribution of sulphide minerals in the Orcadian Basin, indicate several settings where subsurface biological activity could have occurred, and which can be tested by isotopic analysis:

(i) Stratabound diagenetic. The earliest sulphides are pyrite nodules up to $10 \mathrm{~cm}$ size, which grew in the siltstones and sandstones during shallow burial but before significant compaction. They are locally abundant.

(ii) Sulphide mineralization that is directly associated with traces of degraded oil within porous sandstones. Oil was generated from the lacustrine sediments, probably during Carboniferous time and may have been degraded during subsequent CarboniferousPermian uplift (Trewin 1989, Parnell et al. 1998). Syn-depositional hydrothermal. 
Hydrothermal activity which appears to have been syn-diagenetic, i.e. it involved rocks at and below the contemporaneous sediment surface. This includes the mineralization of buried stromatolites (cyanobacterial structures), by galena (lead sulphide) and sphalerite (zinc sulphide), indicating the influx of metals from outside the sedimentary environment, via a deep hydrothermal system. A well-documented example from Warebeth, SW Orkney shows sulphide replacement of the stromatolites before compaction occurred, i.e. very soon after sedimentation ((Muir \& Ridgway 1975)). The later stages of mineralization involve brittle fracture of lacustrine sediment around sulphide-bearing veins, indicating burial to the subsurface. Such deposits are focussed around the inlier of basement rock in SW Orkney, which may have channelled fluid flow and/or heat. Fluid inclusions in the sphalerite are monophase, indicating temperatures probably lower than $70^{\circ} \mathrm{C}$ (Goldstein \& Reynolds 1994), so within the tolerance of thermophile microbes. Syn-diagenetic sulphide precipitation similarly occurred in the northern part of the basin in the Shetland Islands at Matta Taing. At this site, centimetre-scale nodules rich in copper sulphides replaced organic-rich lake sediments, again before significant compaction (Hall \& Donovan 1978).

(iii) Post-depositional hydrothermal. Later hydrothermal mineralization formed pyrite-bearing calcite veins (Fig. 3), which cut all rocks, indicating that they post-dated sedimentation in the basin. The veins occur particularly in the siltstones.

(iv) Sulphide mineralization associated with sediment fluidization and injection (Fig. 3B). As in other basins (Parnell et al. 2013), pyrite is found at the margins of injected sandstone structures that cut transgressively through the siltstones on a centimetre- to metrescale.

Methodology

Sulphide samples were prepared for conventional sulphur isotopic analysis by heavy liquid and hand picking techniques, at the Scottish Universities Environmental Research Centre (SUERC), East Kilbride. Heavy liquid separations were undertaken using suspension in bromoform. Sulphide separates were then analysed by standard techniques (Robinson and Kusakabe, 1975). 5 to 10mg were utilised for isotopic analysis. $\mathrm{SO}_{2}$ gas was liberated by combusting the sulphides with excess $\mathrm{Cu}_{2} \mathrm{O}$ at $1075^{\circ} \mathrm{C}$, in vacuo. Liberated gases were analysed on a VG Isotech SIRA II mass spectrometer, and standard corrections applied to raw $\delta^{66} \mathrm{SO}_{2}$ values to produce true $\delta^{34} \mathrm{~S}$. All $\mathrm{SO}_{2}$ gases were analysed on a VG Isotech SIRA II mass spectrometer. The standards employed were the international standard NBS-123 and IAEA-S-3, and SUERC standard CP-1. These gave $\delta^{34}$ S values of $+17.1 \%$, $31.6 \%$ and $-4.6 \%$ respectively, with $1 \sigma$ reproducibility better than $\pm 0.2 \%$ oround the time of these analyses. Data are reported in $\delta^{34} S$ notation as per mil (\%o) variations from the Vienna Canyon Diablo Troilite (V-CDT) standard.

Results

Sulphur isotope data 
The isotopic composition of sulphur in 23 sulphide samples, together with a sample of gypsum from red bed sediments in the basin, is given in Table 1 . The gypsum has a sulphur isotope composition $\left(\delta^{34} \mathrm{~S}\right)$ of $+19.5 \%$, which represents the sulphate in the depositional environment (i.e. the 'parent' for the sulphides). The sulphides have compositions in the range +18.5 to $-26.7 \%$. The stratabound diagenetic samples (early diagenetic nodules in siltstones, pyrite in sandstones) have compositions similar to the parent sulphate (Fig. 4). Syn-depositional hydrothermal deposits from 3 localities, including replacive sulphides in shales and stromatolites, have compositions in the range +0.2 to -6.4 $\%$. The post-depositional hydrothermal vein deposits have a wide range of composition from +13.8 to $-26.7 \%$. No data were measured for the injectites.

\section{Discussion}

\section{Lacustrine Basins and Sediments}

Sediments deposited in large lake basins have several characteristics which are favourable for microbial growth. They represent reservoirs for nutrients supplied by water flowing into the lake, incorporated into biomass and then released during decay below the sediment-water interface. Lacustrine sequences which consist of cyclic packages of sandstone and mudrock, such as in the Orcadian Basin (Donovan 1980; Andrews \& Trewin 2010), contain extensive interfaces between the sandstone and mudrock. The sandstone is porous and permeable enough to favour microbial colonization and transport, while the organic-rich mudrock would release nutrients during compaction, so the interface may be a favoured habitat for life (Parnell et al. 2013). As the sediments become compacted, their dewatering may cause deformation and mineralization of the fluid escape pathways, which could include biomineralization where springs emerge at the contemporary surface and precipitate their solutes. Such mineralized pathways would include fracture systems and sand injection structures. Many terrestrial lakes accumulate organic carbon, especially where the water column is seasonally or permanently stratified (Dean \& Gorham 1998). All of these characteristics are feasible on early Mars, although the accumulation of organic carbon is likely to have been very limited.

\section{Source of sulphides in Orcadian Basin}

There is widespread evidence for a sulphate-rich depositional environment in the Orcadian Basin, in pseudomorphs after gypsum that occur on many bedding planes (Parnell \& Janaway 1990, Astin \& Rodgers 1991). This sulphate is an obvious source for the sulphides precipitated during burial, and a direct relationship can be observed where the original gypsum crystals are pseudomorphed by pyrite (Parnell \& Janaway 1990). Where sulphides formed before significant compaction, microbial sulphate reduction is strongly implicated, as the only widespread sulphide precipitation mechanism at low temperatures. Together with other examples of syn-diagenetic sulphides in algal breccias (Parnell \& Janaway 1990) and alkaline lake cherts (Parnell 1987), there is extensive evidence for the precipitation of sulphides in the shallow subsurface environment of the Orcadian lake basin. Thermochemical sulphate reduction, a non-biological mechanism, is effective at elevated temperatures from $80-100^{\circ} \mathrm{C}$ upwards, but does not generate strong negative isotopic fractionation (Machel et al. 1995).

In the case of sulphides which formed after sedimentation was complete, i.e. those of post-Devonian age, sulphur could have been available from younger sources, in particular Carboniferous seawater. 
However, the post-Devonian history is more characterized by deep oxidative weathering (Robinson 1985). The close association of the late sulphide veins with the lacustrine siltstones rather implies that the sulphide and host carbonate were derived from within the siltstone rather than by downwards percolation through a thick pile of sediments.

The 'stratabound' group of sulphide samples yield data very similar to the parent sulphate. The similarity is not diagnostic of a specific mechanism of sulphate reduction. It is likely that these sulphides were a product of microbial sulphate reduction, given the low temperatures typical of early diagenesis, but this is not conclusively proven by the isotope data. The vein sulphide samples, by contrast, exhibit a fractionation to a broad range of lighter (more negative) compositions. The lightest sample, at $-26.7 \%$ has a fractionation of $-45 \%$ from the parent sulphate. The broad range and the maximum fractionation are both characteristic features of microbial sulphate reduction (Machel 2001). The syn-depositional hydrothermal samples have a smaller range of compositions than the post-depositional hydrothermal samples. They all have a fractionation of about $20 \%$ from the parent sulphate, which is typical for microbial sulphate reduction in an open system. The greater variation in deep hydrothermal samples represents a greater variation in fluid compositions, and probably variation in the timing of sulphide precipitation. It is likely that the stratabound sulphides were also a product of microbial sulphate reduction, given the low temperatures typical of early diagenesis, but that is not conclusively proven by the isotope data.

Analogue for Mars

Lake sediments may be widespread on Mars (Cabrol \& Grin 2010), including in the Valles Marineris canyon region (Lucchitta 2010, Warner et al. 2013) and the northern plains (Parker et al. 2010), and particularly in craters. The lacustrine sediments of the Orcadian Basin are a valuable analogue for those on Mars. Gale Crater, at $140 \mathrm{~km}$ width, is of comparable size to the Orcadian Basin (Trewin 1989). The lake system in Gale Crater lasted from thousands to millions of years (Grotzinger et al. 2015), also comparable with the long history of Orcadian lacustrine sedimentation (Andrews \& Trewin 2010, Andrews et al. 2016).

Sulphate minerals are widely distributed on Mars (EhImann \& Edwards 2014), so the sulphate-rich nature of the lake waters and sediments of the Orcadian Basin make the deposits an especially pertinent analogue. The occurrence of some sulphides in degraded oil highlights a limitation to the analogy with Mars or other planets. In this case, microbial activity has used hydrocarbons as a source of carbon and energy (as is widely observed in oil reservoirs), and the hydrocarbons exist only as a consequence of earlier carbon fixation by photosynthesis in surface waters. Traces of hydrocarbons occur in the sulphide-bearing veins, so could have supplied carbon to microbial life. Nevertheless, the mineral veins in the Orcadian Basin demonstrate that hydrothermal systems can develop in a lacustrine basin, and circulate fluid and nutrients both during sedimentation and subsequent to it. The post-sedimentation hydrothermal activity is not mere happenstance; it is a natural consequence of the expulsion of fluid from a thick, geothermally heated pile of compacting sediment in a longlived basin. If there is any microbial activity, hydrothermal settings would be preferred habitats as they focus nutrient availability and recharge, and activity is promoted at elevated temperatures. This much can be translated to the exploration of Mars, where the case for investigating the sedimentfills of crater basins has been well made. Although crater lakes would not undergo continued subsidence like the extensional Orcadian Basin, the thermal afterglow of the impact itself is 
expected to have driven hydrothermal activity in craters on Mars as it has on Earth (Rathbun and Squyres 2002). This is thought to explain the occurrence of post-impact silica and sulphate veins observed by rovers in Endeavour Crater and Gale Crater on Mars (Arvidson et al., 2014; Grotzinger et al., 2014). The focus of hydrothermal activity around a basement inlier in the Orcadian Basin is especially pertinent, as this feature is found in many impact craters (e.g. Mount Sharp in Gale Crater) and has been identified as a desirable target for astrobiological sampling on Mars.

The Orcadian injected sandstone structures (Fig. 3c) are centimetre-scale width and transgress the stratigraphy, similar to the injected structure in Gale Crater shown by Grotzinger et al. (2014). Lacustrine successions commonly contain alternating sandstone and mudstone beds, and disturbances (such as meteorite impacts) could trigger gravitational instability stimulatinginjections of the sandstones through the mudstones. Injected structures are conduits for fluid flow, and have a high surface area of sandstone/mudstone interface, making them good habitats (Parnell et al. 2013). Such interfaces also occur form where sand fills crack-like structures in adjacent mud layers, which can open spontaneously during burial and are observed (lithified) both in the Orcadian Basin and in Gale Crater (Donovan \& Foster 1972; Grotzinger et al. 2014; McMahon et al. 2016). Injection and crack-like structures therefore deserve close attention in the search for life.

Both hydrothermal veins and injection structures penetrate to depths of 1-2 km in sedimentary basins, a depth range that includes most deep biosphere activity (McMahon \& Parnell 2014). On Mars, where gravitational compaction and geothermal gradients are milder than on Earth, there is no reason to believe that a deep biosphere could not extend to these depths where liquid water is available (Michalski et al. 2013).

The application of sulphur isotopes in this study has served to prove BSR at depth in the Orcadian Basin, and this the possibility of deep life in lacustrine basins on Mars. The remote measurement of sulphur isotopes on samples on Mars could also have value in the exploration for biological activity there (Franz et al. 2011). However, the fractionation of sulphur isotopes 32 and 34 that is the basis of our conclusion of BSR has evolved over billions of years and is not normally evident in Archean samples on Earth. Evidence of biological activity is nonetheless possible in Archean samples using rarer sulphur isotopes 33 and 36 (e.g. Halevy 2013, Marin-Carbonne et al. 2014). The potential of interrogating Archean sulphide samples is especially pertinent given the equivalent Archean age for the lacustrine samples on Mars. As an understanding of the sulphur isotope systematics on Mars improves, so will the evaluation of whether any anomalous isotopic fractionation could be used as an indicator of possible biology.

\section{Conclusions}

The lacustrine sediments of the Orcadian Basin exhibit evidence for a deep biosphere in several contexts, including syn-depositional hydrothermal deposits, post-depositional hydrothermal deposits, and injected sandstones. Hydrothermal deposits are particularly focussed around a basement uplift. Each of these contexts has potential relevance to Mars. The evidence for microbial activity in these settings in the Orcadian Basin is in sulphide precipitation, some of which has diagnostic sulphur isotope compositions. Although the surface of Mars is sulphate-rich, and sulphide precipitation would be a feasible signature of microbial activity there, this is not essential to the 
analogy. The critical conclusion is that a lacustrine basin contains deep biosphere habitats, and the same habitats could occur on Mars.

\section{Acknowledgements}

The sample of gypsum was kindly provided by John Marshall, University of Southampton. SM was funded by an STFC Aurora studentship (grant ST/1506102/1) and by the NASA Astrobiology Institute (NNA13AA90A Foundations of Complex Life). AJB is funded by NERC support of the Isotope Community Support Facility at SUERC.

\section{References}

Andrews, S.D., Cornwell, D.G., Trewin, N.H., Hartley, A.J. \& Archer, S.G. 2016. A 2.3 million year lacustrine record of orbital forcing from the Devonian of northern Scotland. Journal of the Geological Society, $173,474-488$.

Andrews, S.D. \& Trewin, N.H. 2010. Periodicity determination of lacustrine cycles from the Devonian of northern Scotland. Scottish Journal of Geology, 46, 143-155.

Arp, G. 1995. Lacustrine bioherms, spring mounds, and marginal carbonates of the Ries-ImpactCrater (Miocene, southern Germany). Facies, 33, 35-90.

Arvidson, R.E., Squyres, S.W., Bell, J.F., Catalano, J.G., Clark, B.C., Crumpler, L.S., De Souza, P.A., Fairén, A.G., Farrand, W.H., Fox, V.K. \& Gellert, R., 2014. Ancient aqueous environments at Endeavour crater, Mars. Science, 343, 1248097.

Astin, T.R. \& Rogers, D.A. 1991. 'Subaqueous Shrinkage Cracks' in the Devonian of Scotland reinterpreted. Scottish Journal of Geology, 61, 850-859.

Buatois, L.A. \& Mángano, M.G. 1998. Trace fossil analysis of lacustrine facies and basins.

Palaeogeography, Palaeoclimatology, Palaeoecology, 140, 367-382.

Cabrol, N.A. \& Grin, E.A. 2010. Lake on Mars. Elsevier, Amsterdam.

Cavalazzi, B., Agangi, A., Barbieri, R., Franchi, F. \& Gasparotto, G. 2014. The formation of lowtemperature sedimentary pyrite and its relationship with biologically-induced processes. Geology of Ore Deposits, 56, 395-408.

Dean, W. E. \& Gorham, E. 1998. Magnitude and significance of carbon burial in lakes, reservoirs, and peatlands. Geology, 26, 535-538.

Dichiarente, A.M., Holdsworth, R.E., Dempsey, E.D., Selby, D., McCaffrey, K.J.W., Michie, U. McL., Morgan, G. \& Bonniface, J. 2016. New structural and Re-Os geochronological evidence constraining the age of faulting and associated mineralization in the Devonian Orcadian Basin, Scotland. Journal of the Geological Society, London, 173, 457-473.

Donovan, R.N. 1980. Lacustrine cycles, fish ecology and stratigraphic zonation in the Middle Devonian of Caithness. Scottish Journal of Geology, 16, 35-50. 
Donovan, R.N. \& Foster, R.J. 1972. Subaqueous shrinkage cracks from the Caithness Flagstone Series (middle Devonian) of northeast Scotland. Journal of Sedimentary Petrology, 42, 309-317.

Duncan, W.I. \& Buxton, N.W.K. 1995. New evidence for evaporitic Middle Devonian lacustrine sediments with hydrocarbon source potential on the East Shetland Platform, North Sea. Journal of the Geological Society, 152, 251-258.

Ehlmann, B.L. \& Edwards, C.S. 2014. Mineralogy of the Martian surface. Annual Review of Earth and Planetary Sciences, 42, 291-315.

Fisk, M.R. \& Giovannoni, S.J. 1999. Sources of nutrients and energy for a deep biosphere on Mars. Journal of Geophysical Research, 104, E11805-E11815.

Franz, H.B., Mahaffy, P.R., Kasprzak, W., Lyness, E. \& Raaen, E. (2011). Measuring sulfur isotope ratios from solid samples with the Sample Analysis at Mars instrument and the effects of dead time corrections. 42nd Lunar and Planetary Science, abstract 2800.

Gallagher, M.J., Michie, U. McL., Smith, R.T. \& Haynes, L. 1971. New evidence of uranium and other mineralization in Scotland. Transactions of the Institution of Mining and Metallurgy, 80B, 150-173.

Goldstein,R.H. \& Reynolds, T.J. 1994. Systematics of Fluid Inclusions in Diagenetic Minerals. SEPM Short Course 31. SEPM, Tulsa.

Grotzinger, J.P. and 71 others, 2014. A habitable fluvio-lacustrine environment at Yellowknife Bay, Gale Crater, Mars. Science, 343, 1242777, 1-14.

Grotzinger, J.P. and 46 others, 2015. Deposition, exhumation, and paleoclimate of an ancient lake deposit, Gale crater, Mars. Science, 350, aac7575, 1-12.

Halevy, I. 2013. Production, preservation, and biological processing of mass-independent sulfur isotope fractionation in the Archean surface environment. Procedings of the National Academy of Sciences, 110, 17644-17649.

Hall, A.J. \& Donovan, R.N. 1978. Origin of complex sulphide nodules related to diagenesis of lacustrine sediments of Middle Devonian age from the Shetland Islands. Scottish Journal of Geology, 14, 289-299.

Hutchinson, I.B., Parnell, J., Edwards, H.G.M., Jehlicka, J., Marshall, C.P., Harris, L.H. \& Ingley, R. 2014.Potential for analysis of carbonaceous matter on Mars using Raman spectroscopy. Planetary and Space Science, 103, 184-190.

Kenkmann, T., Jahn, A., Scherler, D. \& Ivanov, B.A. 2005. Structure and formation of a central uplift: A case study at the Upheaval Dome impact crater, Utah. Geological Society of America Special Papers, 384, 85-115.

Lucchitta, B.K. 2010. Lakes in Valles Marineris, in Cabrol, N.A. \& Grin, E.A. (eds), Lakes on Mars. Elsevier, Amsterdam, 111-161.

Machel, H.G. 2001, Bacterial and thermochemical sulfate reduction in diagenetic settings - old and new insights. Sedimentary Geology, 140, 143-175. 
Machel, H.G., Krouse, H.R. \& Sassen, R. 1995. Products and distinguishing criteria of bacterial and thermochemical sulfate reduction. Applied Geochemistry, 10, 373-389.

Marin-Carbonne, J., Rollion-Bard, C., Bekker, A., Rouxel, O., Agangi, A., Cavalazzi, B., WohlgemuthUeberwasser, C.C., Hofmann, A. \& McKeegan, K.D. 2014. Coupled Fe and S isotope variations in pyrite nodules from Archean shale. Earth and Planetary Science Letters, 392, 67-79.

Marshall, J.E.A. \& Hewett, T. 2003. Devonian. In: Evans, D., Graham, C., Armour, A. \& Bathurst, P. (eds)The Millennium Atlas. Geological Society, London.

McMahon, S., van Smeerdijk Hood, A. \& Mcllroy, D., 2016. The origin and occurrence of subaqueous sedimentary cracks. Geological Society, London, Special Publications, 448, SP448-15.

McMahon, S. \& Parnell, J. 2014. Weighing the deep continental biosphere. FEMS Microbiology

McMahon, S., Parnell, J. \& Blamey, N.J.F. 2012. Sampling methane in hydrothermal minerals on Earth and Mars. International Journal of Astrobiology, 11, 163-167. activity on Mars and implications for a deep biosphere. Nature Geoscience, 6, 133-138.

Ming, D.W. and 56 others, 2014. Volatile and organic compositions of sedimentary rocks in Yellowknife Bay, Gale Crater, Mars. Science, 343, 1245267, 1-9.

Muir, R.O. \& Ridgway, J.M. 1975. Sulphide mineralisation of the continental Devonian sediments of Orkney (Scotland). Mineralium Deposita, 10, 205-215. McCutcheon, J., Parnell, J., Preston, L.J., Pickersgill, A.E., Pontefract, A., Sapers, H.M. \& Southam, G. 2013. Impact-generated hydrothermal systems on Earth and Mars. Icarus, 224, 347-363.

Parker, T.J., Grant, J.A. \& Franklin, B.J. 2010. The northern plains: A Martian oceanic basin? in Cabrol, N.A. \& Grin, E.A. (eds), Lakes on Mars. Elsevier, Amsterdam, 249-273.

Parnell, J. 1987. Mineralized Magadi-type cherts in the Devonian of Scotland: support for a model of sulfide deposition in low-temperature alkaline conditions. Economic Geology, 82, 1053-1056. of a global deep subsurface habitat in sand injection complexes. Scientific Reports, doi:10.1038/srep01828.

346 Parnell, J., Carey, P. \& Monson, B. 1998. Timing and temperature of decollement on hydrocarbon 347 source rock beds in cyclic lacustrine successions. Palaeogeography, Palaeoclimatology,

348 Palaeoecology, 140, 121-134. system, Orkney, Scotland. Ore Geology Reviews, 4, 445-460. 
Plant, J.A., Forrest, M.D., Hodgson, J.F., Smith, R.T. \& Stevenson, A.G. 1986. Regional geochemistry in the detection and modelling of mineral deposits. In: Thornton, I. \& Howarth, R.J. (eds) Applied Geochemistry in the 1980s. Graham \& Trotman, London, 103-139.

Raiswell, R. \& Berner, R.A. 1986. Pyrite and organic matter in Phanerozoic normal marine shales. Geochimica et Cosmochimica Acta, 50, 1967-1976.

Rathbun, J.A. \& Squyres, S.W. 2002. Hydrothermal systems associated with Martian impact craters. Icarus, 157, 362-372.

Robinson, B. W. \& Kusakabe, M., 1975. Quantitative preparation of sulfur dioxide for 34S/32S analyses from sulphides by combustion with cuprous oxide. Analytical Chemistry 47, 1179-1181.

Robinson, M.A. 1985. Palaeomagnetism of volcanics and sediments of the Eday Group, southern Orkney. Scottish Journal of Geology, 21, 285-300.

Schnurrenberger, S., Russell, J. \& Kelts, K. 2003. Classification of lacustrine sediments based on sedimentary components. Journal of Paleolimnology, 29, 141-154.

Schopf, J.W., Farmer, J.D., Foster, I.S., Kudryavtsev, A.B., Gallardo, V.A. \& Espinoza, C., 2012. Gypsum-permineralized microfossils and their relevance to the search for life on Mars. Astrobiology, $12,619-633$.

Strachan, R.A. 2003. The metamorphic basement geology of Mainland Orkney and Graemsay. Scottish Journal of Geology, 39, 145-149.

Trewin, N.H. 1989. The petroleum potential of the Old Red Sandstone of northern Scotland. Scott. Jour. Geol., 25, 201-225.

Warner, N.H., Sowe, M., Gupta, S., Dumke, A. \& Goddard, K. 2013. Fill and spill of giant lakes in the eastern Valles Marineris region of Mars. Geology, 41, 675-678.

Weiss, B.P., Yung, Y.L. \& Nealson, K.H. 2000. Atmospheric energy for subsurface life on Mars? Proceedings National Academy of Sciences, 97, 1395-1399.

\section{Figure captions}

Fig. 1. Schematic cross-section across a lacustrine basin, showing diversity of settings which may support subsurface microbial activity.

Fig. 2. Map of central part of Orcadian Basin, northern Scotland, showing localities for sulphide and sulphate samples. Outcrop of basement uplift occurs in SW Orkney. Localities A, Achanarras, B, Broadhaven, C, Castlehill, E, East Scapa, G, Graemsay, K, Ackergill, N, Breck Ness, P, Pennyland, S, Spittal, SH, Wick South Head, W, Warebeth, X, Staxigoe. 
Fig. 3. Settings for sulphide mineralization in the sediments of the Orcadian Basin. A, Concretionary stromatolites replaced by galena (lead sulphide), Warebeth. Field width $2 \mathrm{~cm}$. B, Margin of calcite vein through siltstone, with pyrite at interface (arrowed), Spittal. C, Sandstone injection structure cross-cutting siltstone host, The Haven (transgressive relationship arrowed). Pyrite occurs at sandstone/siltstone boundary at a microscopic level. Compass scale $5 \mathrm{~cm}$ wide.

Fig. 4. Histogram of sulphur isotope data from sulphides in the Orcadian Basin.

Table 1. Samples of sulphide and sulphate minerals used for sulphur isotope analysis.

\begin{tabular}{|c|c|c|c|c|c|}
\hline Locality & Lab code & Mineral & setting & style & $\overline{\delta^{34} \mathrm{~S}(\% \circ)}$ \\
\hline East Scapa & 61 & gypsum & $\begin{array}{l}\text { Massive in } \\
\text { red beds }\end{array}$ & $\begin{array}{l}\text { Primary sulphate } \\
\text { (stratabound) }\end{array}$ & 19.5 \\
\hline Ackergill & 2109 & pyrite & $\begin{array}{l}\text { Nodule in } \\
\text { black shale }\end{array}$ & $\begin{array}{l}\text { Stratabound } \\
\text { diagenetic }\end{array}$ & 14.4 \\
\hline Castlehill & 2110 & pyrite & $\begin{array}{l}\text { Nodule in } \\
\text { shale }\end{array}$ & $\begin{array}{l}\text { Stratabound } \\
\text { diagenetic }\end{array}$ & 14.5 \\
\hline Pennyland & 2113 & pyrite & $\begin{array}{l}\text { Nodule in } \\
\text { sandstone }\end{array}$ & $\begin{array}{l}\text { Stratabound } \\
\text { diagenetic }\end{array}$ & 18.5 \\
\hline Pennyland & 2114 & pyrite & $\begin{array}{l}\text { Nodule in } \\
\text { sandstone }\end{array}$ & $\begin{array}{l}\text { Stratabound } \\
\text { diagenetic }\end{array}$ & 17.3 \\
\hline Pennyland & 2115 & pyrite & $\begin{array}{l}\text { Nodule in } \\
\text { shale }\end{array}$ & $\begin{array}{l}\text { Stratabound } \\
\text { diagenetic }\end{array}$ & 16.1 \\
\hline Breckness & 20 & pyrite & $\begin{array}{l}\text { Nodule in } \\
\text { sandstone }\end{array}$ & $\begin{array}{l}\text { Stratabound } \\
\text { diagenetic }\end{array}$ & 17.3 \\
\hline Matta Taing & SS28 & Cu sulphides & $\begin{array}{l}\text { Replacive in } \\
\text { shale }\end{array}$ & $\begin{array}{l}\text { Syn-depositional } \\
\text { hydrothermal }\end{array}$ & -4.1 \\
\hline Warebeth & SS29 & galena & $\begin{array}{l}\text { Replacive in } \\
\text { stromatolite }\end{array}$ & $\begin{array}{l}\text { Syn-depositional } \\
\text { hydrothermal }\end{array}$ & -0.6 \\
\hline Warebeth & 145 & galena & Vein in shale & $\begin{array}{l}\text { Syn-depositional } \\
\text { hydrothermal }\end{array}$ & 0.0 \\
\hline Graemsay & 146 & galena & $\begin{array}{l}\text { Replacive in } \\
\text { stromatolite }\end{array}$ & $\begin{array}{l}\text { Syn-depositional } \\
\text { hydrothermal }\end{array}$ & -0.6 \\
\hline Warebeth & 147 & galena & Vein in shale & $\begin{array}{l}\text { Syn-depositional } \\
\text { hydrothermal }\end{array}$ & -0.1 \\
\hline Warebeth & 148 & galena & $\begin{array}{l}\text { Replacive in } \\
\text { stromatolite }\end{array}$ & $\begin{array}{l}\text { Syn-depositional } \\
\text { hydrothermal }\end{array}$ & 0.2 \\
\hline Matta Taing & 149 & Cu sulphides & $\begin{array}{l}\text { Replacive in } \\
\text { shale }\end{array}$ & $\begin{array}{l}\text { Syn-depositional } \\
\text { hydrothermal }\end{array}$ & -1.8 \\
\hline Matta Taing & 150 & Cu sulphides & $\begin{array}{l}\text { Replacive in } \\
\text { shale }\end{array}$ & $\begin{array}{l}\text { Syn-depositional } \\
\text { hydrothermal }\end{array}$ & -6.4 \\
\hline Achanarras & $\mathrm{ACH}$ & pyrite & $\begin{array}{l}\text { Vein through } \\
\text { shale }\end{array}$ & $\begin{array}{l}\text { Post-depositional } \\
\text { hydrothermal }\end{array}$ & 7.9 \\
\hline Achanarras & $\mathrm{ACH} 32$ & pyrite & $\begin{array}{l}\text { Vein through } \\
\text { shale }\end{array}$ & $\begin{array}{l}\text { Post-depositional } \\
\text { hydrothermal }\end{array}$ & -3.8 \\
\hline Staxigoe & 135 & pyrite & $\begin{array}{l}\text { Vein through } \\
\text { shale }\end{array}$ & $\begin{array}{l}\text { Post-depositional } \\
\text { hydrothermal }\end{array}$ & 6.9 \\
\hline
\end{tabular}




\begin{tabular}{|l|l|l|l|l|l|}
\hline $\begin{array}{l}\text { Wick South } \\
\text { Head }\end{array}$ & 136 & pyrite & $\begin{array}{l}\text { Vein through } \\
\text { shale }\end{array}$ & $\begin{array}{l}\text { Post-depositional } \\
\text { hydrothermal }\end{array}$ & 13.8 \\
\hline The Haven & 137 & pyrite & $\begin{array}{l}\text { Vein through } \\
\text { shale }\end{array}$ & $\begin{array}{l}\text { Post-depositional } \\
\text { hydrothermal }\end{array}$ & -26.7 \\
\hline Broadhaven & 138 & pyrite & $\begin{array}{l}\text { Vein through } \\
\text { shale }\end{array}$ & $\begin{array}{l}\text { Post-depositional } \\
\text { hydrothermal }\end{array}$ & 9.5 \\
\hline The Haven & SS2 & pyrite & $\begin{array}{l}\text { Vein through } \\
\text { shale }\end{array}$ & $\begin{array}{l}\text { Post-depositional } \\
\text { hydrothermal }\end{array}$ & 10.1 \\
\hline Spittal & 2111 & pyrite & $\begin{array}{l}\text { Vein through } \\
\text { shale }\end{array}$ & $\begin{array}{l}\text { Post-depositional } \\
\text { hydrothermal }\end{array}$ & 4.3 \\
\hline The Haven & 2112 & pyrite & $\begin{array}{l}\text { Vein through } \\
\text { shale }\end{array}$ & $\begin{array}{l}\text { Post-depositional } \\
\text { hydrothermal }\end{array}$ & -11.1 \\
\hline
\end{tabular}

393

394

395 